\title{
Alien Pests Can Spread Quickly: Wooly Ash Aphid Prociphilus fraxinifolii (Hemiptera: Eriosomatidae) Has Occupied Europe in 18 Years
}

\author{
Marina J. Orlova-Bienkowskaja * $*$ and Andrzej O. Bieńkowski
}

check for updates

Citation: Orlova-Bienkowskaja, M.J.; Bieńkowski, A.O. Alien Pests Can Spread Quickly: Wooly Ash Aphid Prociphilus fraxinifolii (Hemiptera: Eriosomatidae) Has Occupied Europe in 18 Years. Forests 2021, 12, 1176. https://doi.org/10.3390/f12091176

Academic Editor: Young-Seuk Park

Received: 7 July 2021

Accepted: 27 August 2021

Published: 30 August 2021

Publisher's Note: MDPI stays neutral with regard to jurisdictional claims in published maps and institutional affiliations.

Copyright: (c) 2021 by the authors. Licensee MDPI, Basel, Switzerland. This article is an open access article distributed under the terms and conditions of the Creative Commons Attribution (CC BY) license (https:/ / creativecommons.org/licenses/by/ $4.0 /)$.

\author{
A.N. Severtsov Institute of Ecology and Evolution, Russian Academy of Sciences, 119071 Moscow, Russia; \\ bienkowski@yandex.ru \\ * Correspondence: marinaorlben@yandex.ru
}

\begin{abstract}
Prociphilus fraxinifolii (woolly ash aphid) is a pest of ash trees (Fraxinus spp.). This species, which is native to North America, was first recorded in Europe in 2003, in Budapest, and then began to spread quickly. In 2019-2021, we first detected P. fraxinifolii in Belarus (Brest) and eight regions of European Russia, namely Astrakhan, Nizhny Novgorod, Samara, Saratov, Smolensk, Tambov, Volgograd and Voronezh regions. By 2021, P. fraxinifolii has spread over a vast territory in Europe: from Spain in the west to the Volga River in the east. The distance between the westernmost and easternmost localities is $4180 \mathrm{~km}$. The known range is disjunctive: Armenia, Belarus, Bulgaria, Germany, Great Britain, Hungary, Poland, Romania, Spain and 16 regions of European Russia. This case indicates that some alien pests are able to occupy the whole of Europe in less than two decades after the first record in the continent. It is known that $P$. fraxinifolii can infest native ash species F. excelsior, but all our findings, as well as most findings indicated in the literature, were on F. pennsylvanica introduced from North America. We never found P. fraxinifolii on F. excelsior even near infested F. pennsylvanica trees.
\end{abstract}

Keywords: Prociphilus fraxinifolii; Fraxinus pennsylvanica; ash trees; aphids; pests; insects; woolly ash aphid; ash leaf curl aphid

\section{Introduction}

New alien insects from other continents appear and establish in Europe every year [1]. Once established, most alien species do not spread throughout Europe, with about $40 \%$ of the species only present in one or two countries [2]. However, some species, including pests, occupy the whole continent quickly [2]. The current article is about one such quickly spreading alien pests-Prociphilus (Meliarhizophagus) fraxinifolii (Riley, 1879) (Hemiptera: Eriosomatidae).

Prociphilus fraxinifolii (woolly ash aphid, ash leaf curl aphid) is native to North America and develops on ash trees (Fraxinus spp.) [3]. It has been established in South Africa, Chile, China, Iran and Europe [3]. It was first recorded in Europe in 2003, in Budapest (Hungary) [4], and then it was detected in Ukraine in 2005 [5], Serbia in 2006 [6], Bulgaria in 2007 [7], Great Britain and Spain in 2011 [8,9], Poland in 2012 [10], Germany and Slovenia in 2015 [3,11], European Russia and Romania in 2017 [12-14] and Armenia in 2019 [15].

In 2019-2021, we surveyed ash trees in different regions of European Russia and Belarus, because we were involved in the project on the emerald ash borer Agrilus planipennis Fairmaire, 1888 [16]. During these surveys, we noticed P. fraxinifolii in many localities and found out that its current range is much wider than was supposed before. Here we present the information about our findings and summarize all available information about the current distribution of P. fraxinifolii in Europe. 


\section{Materials and Methods}

\subsection{Collection}

In 2019-2021, we examined about 2500 F. pennsylvanica and more than 1000 F. excelsior trees in nine regions of European Russia and one region of Belarus (Table 1). In 2019-2021, we monitored the distribution of P. fraxinifolii in Zelenograd City (Moscow Region), where the pest was discovered first in 2017 [12].

Table 1. Localities of detection of P. fraxinifolii in 2019-2021.

\begin{tabular}{|c|c|c|c|c|c|}
\hline $\begin{array}{c}\text { Country/ } \\
\text { Region }\end{array}$ & Locality & $\begin{array}{c}\text { Number of } \\
\text { Examined } \\
\text { F. pennsylvanica } \\
\text { Trees and Kind of } \\
\text { Planting }{ }^{2}\end{array}$ & $\begin{array}{l}\text { Number of } \\
\text { Examined } \\
\text { F. excelsior Trees } \\
\text { and Kind of } \\
\text { Planting }\end{array}$ & $\begin{array}{c}\text { Number of } \\
\text { Infested } \\
\text { F. pennsylvanica } \\
\text { Trees }\end{array}$ & Date of Survey \\
\hline $\begin{array}{c}\text { Belarus } \\
\text { Brest } \\
\text { Russia }\end{array}$ & Brest & $>100 \mathrm{U}$ & 0 & 3 & 19 June 2021 \\
\hline Astrakhan & Astrakhan City & $>100 \mathrm{U}$ & 0 & 2 & 11 May 2021 \\
\hline Astrakhan & Nikolskoe & $>50 \mathrm{R}$ & 0 & 2 & 13 August 2020 \\
\hline Astrakhan & Astrakhanskaya Fishka & $>100 \mathrm{~F}$ & 0 & 1 & 15 May 2021 \\
\hline Moscow & Zelenograd & $>500 \mathrm{U}$ & $20 \mathrm{U}$ & $>20$ & $\begin{array}{c}\text { July and August } 2020 \\
\text { and July } 2021\end{array}$ \\
\hline Moscow & Alabushevo & $>50 \mathrm{R}$ & 0 & 2 & 8 August 2019 \\
\hline Moscow & Moscow City & $>100 \mathrm{U}$ & 0 & 3 & 28 July 2020 \\
\hline Nizhny Novgorod & Nizhny Novgorod City & $>100 \mathrm{U}$ & $>100 \mathrm{~F}$ & 10 & 19 August 2020 \\
\hline Samara & Samara City & $>100 \mathrm{U}$ & 0 & 1 & 16 August 2020 \\
\hline Saratov & Saratov City & $>100 \mathrm{U}$ & 0 & 5 & 10 August 2020 \\
\hline Saratov & Usovka Island & $>100 \mathrm{~F}$ & 0 & 3 & 15 August 2020 \\
\hline Smolensk & Vyazma & $107 \mathrm{U}$ & $67 \mathrm{U}$ & 3 & 3 August 2019 \\
\hline Smolensk & Sychevka & $32 \mathrm{U}$ & 0 & 1 & 5 August 2019 \\
\hline Tambov $^{1}$ & Tambov City & $>100 \mathrm{U}$ & 0 & 1 & 17 August 2020 \\
\hline Volgograd & Volgograd City & $>100 \mathrm{U}$ & 0 & 2 & 11 August 2020 \\
\hline Voronezh & Borisoglebsk & $24 \mathrm{U}$ & $21 \mathrm{U}$ & 1 & 12 August 2019 \\
\hline Voronezh & Vorona River valley & $>100 \mathrm{~F}$ & $>500 \mathrm{~F}$ & 2 & 12 August 2019 \\
\hline Voronezh & Povorino & $>100 \mathrm{U}$ & 0 & 12 & 13 August 2019 \\
\hline Voronezh & Rossosh & $>100 \mathrm{P}$ & $1 P$ & $>20$ & 13 August 2019 \\
\hline Voronezh & Kantemirovka & $>150 \mathrm{U}$ & 0 & $>50$ & 14 August 2019 \\
\hline Voronezh & Voronezh City & $>500 \mathrm{U}$ & $>500 \mathrm{~F}, \mathrm{U}$ & 5 & July and August 2021 \\
\hline
\end{tabular}

${ }^{1}$ The survey of ash trees in Tambov was made by Roman Ishin. The survey in all other regions was made by the authors of the article.

${ }^{2}$ Kind of plantings: $\mathrm{U}$ - urban, $\mathrm{R}$-roadside, $\mathrm{F}$ - forest, $\mathrm{P}$ - protective forest belt around the field.

When we detected the characteristic leaf nests (Figure 1), we collected aphids, placed them in alcohol and then examined them in the laboratory. The specimens were deposited in the collection of the second author.

\subsection{Identification}

Mature apterous and alate females, as well as immature apterous females and nymphs of alate females, were found in leaf nests in all localities. Slides of alate and apterous females were prepared in Berlese fluid and examined under the microscope. The species was identified according to Blackman and Eastop [17]. Prociphilus (M.) fraxinifolii can be distinguished from other species of the genus by the following characteristics (Figure 2). Alate females have 1-3 (1-5 after Blackman and Eastop [17]) irregularly shaped broad secondary rhinaria on antennomere 6 , differing in shape from the narrow transverse secondary rhinaria on antennomere 3 ; antennomere 3 as long as 2.6-3.2 $\times$ antennomere 2 ; length of antennomere 2 as long as 1.4-1.5 $\times$ its width, bearing 3 or 4 hairs. Apterous adult females of $P$. (M.) fraxinifolii differ from morphologically close $P$. (Pulvius) probosceus in rostrum very short, much shorter than body, with apical segment (segments $4+5$ ) with 3 accessory hairs (2 hairs after Blackman and Eastop [17]). Prociphilus probosceus has more than 10 hairs. 


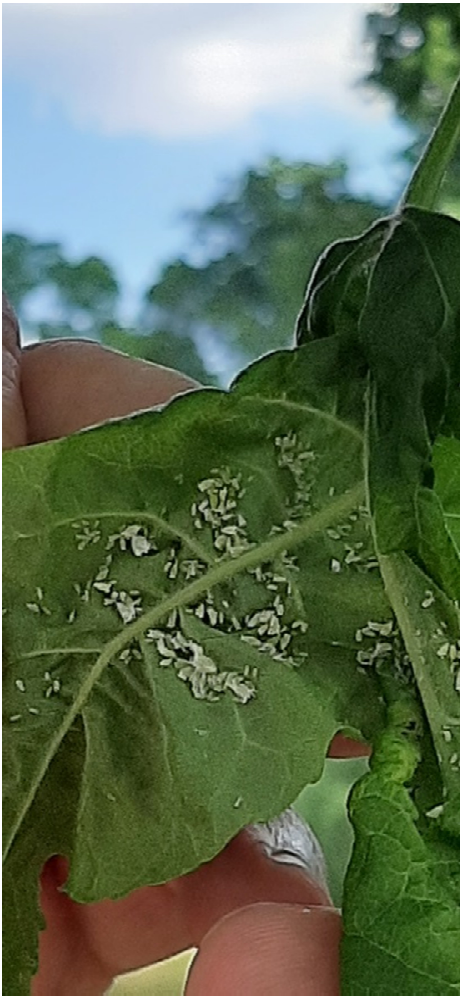

(a)

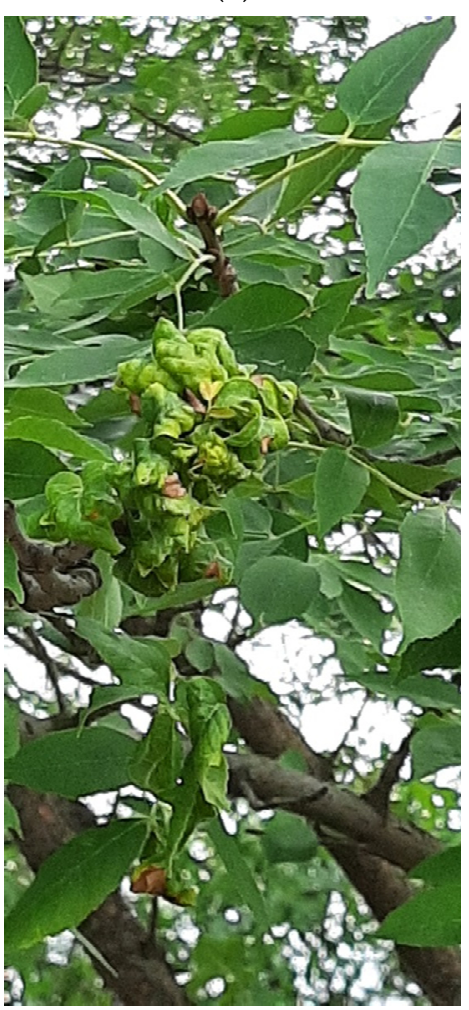

(c)

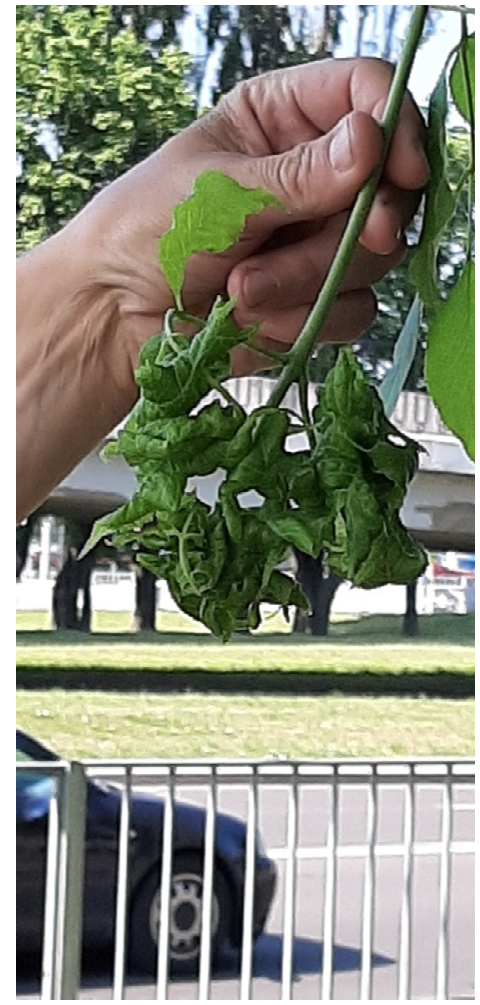

(b)

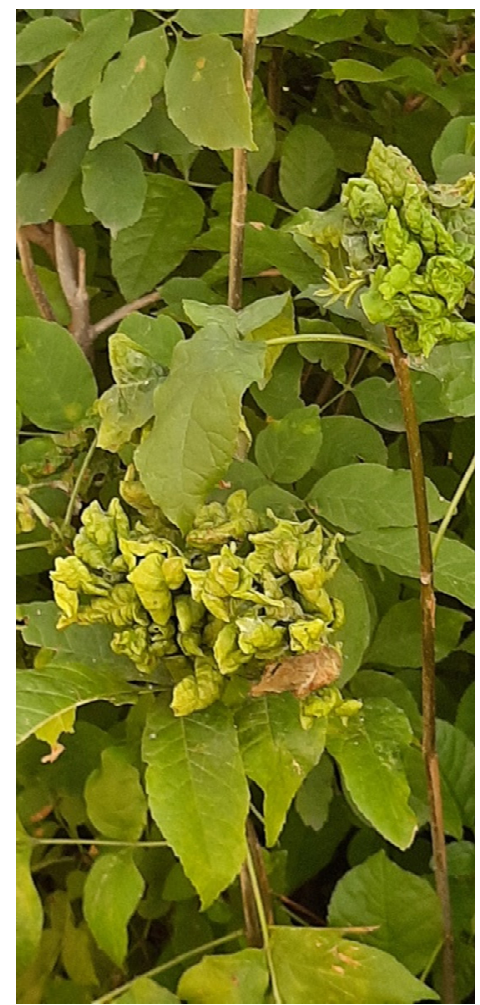

(d)

Figure 1. Leaf nests of Prociphilus fraxinifolii in different regions: $(\mathbf{a}, \mathbf{b})$ in Brest (Belarus), (c) in Nikolskoe (Astrakhan region) and (d) in Nizhny Novgorod. 


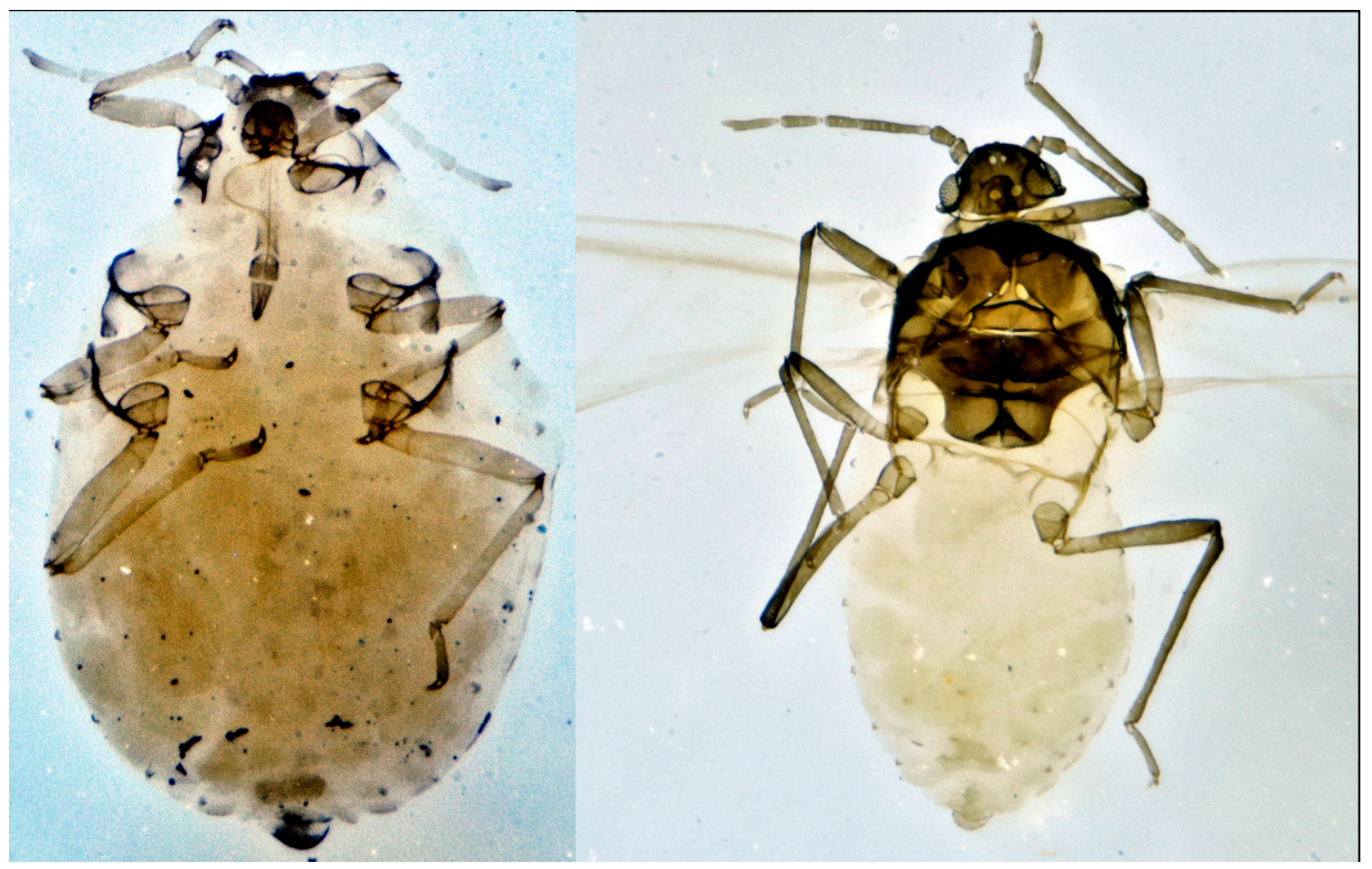

(a)

(b)

Figure 2. Prociphilus fraxinifolii collected from leaf nests. (a) Adult apterous female with embryons collected in Kantemirovka (Voronezh Region) and (b) alate female collected in Sychevka (Smolensk Region).

Mature and immature apterous viviparous females of $P$. (M.) fraxinifolii are pale green or pale yellow. Nymphs pale green with thorax pale yellow. Alate viviparous females have grey head and thorax and pale green abdomen. Ocelli and compound eyes (in alate females and nymphs) are black. All morphs are covered by white wax; mature and immature apterous females bear thick curved white wax threads.

\section{Results}

We have detected P. fraxinifolii in 28 localities of nine regions of European Russia and in one locality in Belarus (Table 1 and Figure 3).

Prociphilus fraxinifolii was detected both in artificial plantings of F. pennsylvanica (urban, roadside and field protection plantings) and in self-seeding trees in riparian forests. The rate of infestation varied from 1 to $30 \%$ of F. pennsylvanica trees examined in each locality. The leaf nests usually are seen on seedlings or epicormic shoots, but sometimes also on the branches of large trees. Usually the pest infests from one to five trees standing nearby, while other trees of F. pennsylvanica in the same street or park have no signs or symptoms of infestation. Groups of infested trees are scattered throughout the city.

Prociphilus fraxinifolii was never found to infest F. excelsior in European Russia. Examination of more than 1000 European ash trees (F. excelsior) in seven localities has not revealed any cases of infestation, even in the presence of infested F. pennsylvanica in these localities (Table 1).

Monitoring of P. fraxinifolii in Zelenograd (Moscow Region) has shown that almost all trees, that were found to be infested in 2017 were still infested by the pest in 2021. Moreover, new infestations in other streets of the city were detected. It indicates that $P$. fraxinifolii has been established in the city, and its population is likely to increase rather than decrease. In spite of this, the economic effect of the pest in the city seems insignificant (at least for now). Some trees have lost their ornamental value because of the leaf nests, but no cases of trees killed by the pest have been recorded. The same situation was observed in other regions 
examined. Prociphilus fraxinifolii has become common, especially in the southern regions, but it seems that it does not kill the trees.

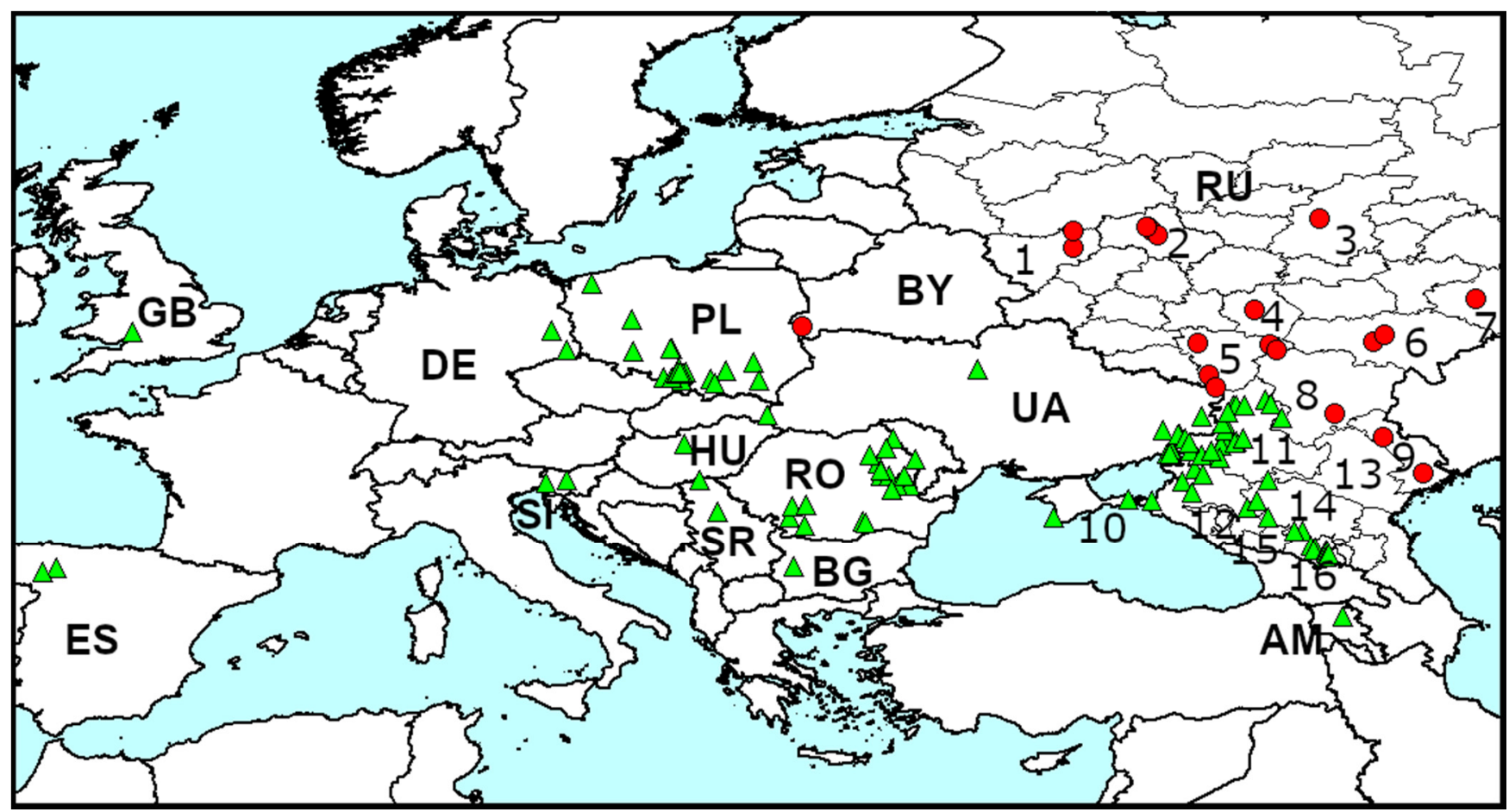

Figure 3. Localities of detection of Prociphilus fraxinifolii in Europe. Red dots-our findings. Green triangles-localities indicated in published sources [3-15,18-22]. AM-Armenia, BG-Bulgaria, BY-Belarus, DE-Germany, ES-Spain, GB-Great Britain, HU—Hungary, PL—Poland, RO—Romania, SI—Slovenia, SR—Serbia, UA—Ukraine, RU—Russia: 1— Smolensk Region, 2-Moscow Region, 3-Nizhny Novgorod Region, 4-Tambov Region, 5-Voronezh Region, 6-Saratov Region, 7-Samara Region, 8-Volgograd Region, 9-Astrakhan Region, 10-Republic of Crimea, 11-Rostov Region, 12-Krasnodar Territory, 13-Republic of Kalmykia, 14-Stavropol Territory, 15-Kabardino-Balkar Republic, 16-Republic of North Ossetia. This map was made using DIVA-GIS 7.5 software [23].

\section{Discussion}

\subsection{General Distribution in Europe}

Prociphilus fraxinifolii has not been recorded in Belarus before. This species is absent in the review of the Aphids of the family Eriosomatidae of Belarus [24]. We have detected P. fraxinifolii in Belarus and eight regions of Europe Russia: Astrakhan, Nizhny Novgorod, Samara, Saratov, Smolensk, Tambov, Volgograd and Voronezh. These findings, as well as recent findings in seven other regions of European Russia (Moscow Region, Rostov Region, Crimea, Krasnodar Territory, Republic of Kalmykia, Stavropol Territory, KabardinoBalkaria and North Ossetia) [12,20] and in Armenia [15], indicate that P. fraxinifolii has become widespread and common in Eastern Europe.

There is no reliable information about pathways of spread of $P$. fraxinifolii in European Russia and Belarus. It was hypothesized that $P$. fraxinifolii could arrive from one region of Europe to another on air currents or on nursery stock [3].

Localities of $P$. fraxinifolii detection in Europe form several clusters surrounded by territories, where the pest has not been found (Figure 3). This could indicate that the range is disjunctive because the pest was unintentionally introduced to some regions, while it was not introduced to others. Such disjunctive formation of range is typical for alien pests, in particular, for alien pests associated with ash trees [25]. On the other hand, the absence of findings in some territories could simply reflect the absence of surveys. Surprisingly, the information about distribution of P. fraxinifolii in Europe is scarce. There is no map or distributional information in EPPO Global Database [26]. No records of this species in 
Europe are included to Global Biodiversity Information Facility [27] and only one record is included to European Alien Species Information Network [28]. The surveys are necessary to reveal if $P$. fraxinifolii occurs in territories surrounded by the known range. There are no data for France, Switzerland, Italy and several other countries.

\subsection{Host Plants and Ecological Impact}

Prociphilus fraxinifolii in Europe infests mainly F. pennsylvanica introduced from North America. We have not found leaf nests of $P$. fraxinifolii on F. excelsior even near infested F. pennsylvanica trees. Few cases of infestation of F. excelsior native to Europe are known [3]. Thus the potential impact of the pest in different countries would be different depending on the frequency of occurrence of F. pennsylvanica. In particular, F. pennsylvanica is rather rare in Great Britain. Prociphilus fraxinifolii was recorded there only once (2011) [8] and was not found in the subsequent years (Edward A. Baker, personal communication). Fraxinus pennsylvanica is one of the most common trees in urban and roadside plantings and in field protective belts in European Russia [29]. It also is an invasive plant that has established and become abundant in river valleys. Therefore, it is not surprising that $P$. fraxinifolii also has become common and widespread in European Russia.

At first glance it seems that the economic and ecological impact of $P$. fraxinifolii is not significant even in the regions, where this pest is abundant. However, it should be taken into account that $F$. pennsylvanica trees in European Russia are now affected by the most serious alien pest, the emerald ash borer Agrilus planipennis. Agrilus planipennis inevitably will spread to neighboring countries soon [30]. The trees affected by $A$. planipennis often produce epicormic shoots to survive [31], but according to our observations epicormic shoots are very vulnerable to $P$. fraxinifolii. Development of $P$. fraxinifolii on roots and epicormic shoots potentially could worsen the condition of ash trees damaged by A. planipennis.

\section{Conclusions}

1. We have first detected P. fraxinifolii in Belarus and eight regions of Europe Russia: Astrakhan, Nizhny Novgorod, Samara, Saratov, Smolensk, Tambov, Volgograd and Voronezh.

2. By 2021, i.e., in just 18 years after the first record in Europe, P. fraxinifolii has spread over the vast territory: from Spain in the west to the Volga River in the east. The distance between the westernmost and easternmost localities is $4180 \mathrm{~km}$.

3. The known range is disjunctive and includes Armenia, Belarus, Bulgaria, Germany, Great Britain, Hungary, Poland, Romania, Spain and 16 regions of European Russia. Absence in the intervening regions could be due to lack of observations, scarcity of the host tree, F. pennsylvanica, or variable movement of infested nursery stock.

Author Contributions: Conceptualization, M.J.O.-B.; investigation, M.J.O.-B. and A.O.B.; writingoriginal draft preparation, M.J.O.-B.; writing—review and editing, A.O.B.; visualization, M.J.O.-B. All authors have read and agreed to the published version of the manuscript.

Funding: The study was funded by the RUSSIAN SCIENCE FOUNDATION, grant number 21-74-20001.

Data Availability Statement: All new data created in this study are included to the text.

Acknowledgments: We are grateful to R.N. Ishin for the survey of ash trees in Tambov City and collecting specimens of $P$. fraxinifolii there, to E.A. Baker for the information about P. fraxinifolii in Great Britain, and to S. Halbert and the anonymous reviewer for the valuable comments on the manuscript.

Conflicts of Interest: The authors declare no conflict of interest. The funders had no role in the design of the study; in the collection, analyses or interpretation of data; in the writing of the manuscript; or in the decision to publish the results. 


\section{References}

1. Seebens, H.; Blackburn, T.M.; Hulme, P.E.; van Kleunen, M.; Liebhold, A.M.; Orlova-Bienkowskaja, M.; Pyšek, P.; Schindler, S.; Essl, F. Around the world in 500 years: Inter-regional spread of alien species over recent centuries. Glob. Ecol. Biogeogr. 2021. [CrossRef]

2. Roques, A. Taxonomy, time and geographic patterns. Alain Roques. Taxonomy, time and geographic patterns. Chapter 2. Alien terrestrial arthropods of Europe. BioRisk 2010, 4, 11-26. [CrossRef]

3. Hałaj, R.; Osiadacz, B. Woolly ash aphid—is the alien bug posing a threat to European ash trees? -A review. Plant Protect. Sci. 2017, 53, 127-133. [CrossRef]

4. Remaudière, G.; Ripka, G. Arrivée en Europe (Budapest, Hongrie) du puceron des frenes américains, Prociphilus (Meliarhizophagus) fraxinifolii (Hemiptera, Aphididae, Eriosomatinae, Pemphigini). Rev. Française D'entomologie 2003, 25, 152.

5. Chumak, V.O.; Zhuravlev, V.V.; Migal, A.V.; Galats, V.V. New invasive species of Aphidinea in the Ukraine. Ukr. Entomofaunistyka 2016, 7, 97. (In Ukrainian)

6. Petrović-Obradović, O.; Tomanović, Ž.; Poljaković-Pajnik, L.; Vučetić, A. An invasive species of aphid, Prociphilus fraxinifolii (Hemiptera, Aphididae, Eriosomatinae), found in Serbia. Arch. Biol. Sci. 2007, 59, 9-10. [CrossRef]

7. Trenchev, G.; Trencheva, K. Prociphilus fraxinifolii Riley (Hemiptera, Aphididae, Eriosomatinae) a species new to the Bulgarian fauna. Sustain. For. 2009, 59, 60-79.

8. Baker, E.A.; Martin, J.H. Prociphilus fraxinifolii (Hemiptera: Aphididae), a species new to Britain. Br. J. Entomol. Nat. Hist. 2011, 24, 221-223.

9. Pérez Hidalgo, N.; Mier Durante, M.P. First record of Prociphilus (Meliarhizophagus) fraxinifolii (Riley) [Hemiptera: Aphididae] in the Iberian Peninsula. EPPO Bull. 2012, 42, 142-145. [CrossRef]

10. Hałaj, R.; Osiadacz, B.; Poljaković-Pajnik, L. Górny Śląsk-polski przyczółek zdobyty przez obcą mszycę Prociphilus (Meliarhizophagus) fraxinifolii (Riley, 1879). Acta Entomol. Sil. 2016, 24, 1-9.

11. Seljak, G. New alien phytophagous insect species to the fauna of Slovenia. Acta Entomol. Slov. 2017, 25, 141-158.

12. Bieńkowski, A.O.; Orlova-Bienkowskaja, M.J. Establishment of the new alien pest wooly ash aphid, Prociphilus (Meliarhizophagus) fraxinifolii (Riley, 1979) in European Russia. Balt. For. 2018, 24, 185-188.

13. Olenici, N.; Blaga, T.; Tomescu, R.; Gogu, I.; Țilea, G. Cinci specii de insecte forestiere invazive noi în partea de nord-est a României. Bucov. For. 2018, 18, 119-135. [CrossRef]

14. Nețoiu, C.; Tomescu, R.; Olenici, N.; Buzatu, A.; Bălăcenoiu, F.; Iliescu, O. The invazive insect species in the Oltenia region (Romania). Oltenia. Studii și comunicări. Muz. Olten. Craiova 2018, 34, 111-123.

15. Gubin, A.I. Four invasive alien phytophagous insects new to Armenia. Phytoparasitica 2021, 49, 163-166. [CrossRef]

16. Volkovitsh, M.G.; Bieńkowski, A.O.; Orlova-Bienkowskaja, M.J. Emerald ash borer approaches the borders of the European union and Kazakhstan and is confirmed to infest European ash. Forests 2021, 12, 691. [CrossRef]

17. Blackman, R.L.; Eastop, V.F. Aphids on the World's Plants. An online Identification and Information Guide. 2016. Available online: http: / / www.aphidsonworldsplants.info (accessed on 6 July 2021).

18. Martynov, V.V.; Nikulina, T.V. Modern distribution of the north American ash aphid Prociphilus (Meliarhizophagus) fraxinifolii (Riley, 1979) (Hemiptera: Aphididae: Eriosomatinae) in Southern Russia. In Proceedings of the 22nd International Scientific Conference Biological Diversity of the Caucasus and the South of Russia, Grozny, Russia, 4-6 November 2020; pp. 324-327.

19. Martynov, V.V.; Nikulina, T.V. Prociphilus (Meliarhizophagus) fraxinifolii (Riley, 1979) (Hemiptera: Aphididae: Eriosomatinae) -A new invasive North American aphid species in the Donbass. In Proceedings of the Current Problems and Prospects of Integrated Plant Protection, International Scientific-Practical Conference of Young Scientists and Specialists, Dedicated to the 70th Anniversary of the Institute of Plant Protection of NAAS of Ukraine, Kyiv, Ukraine, 7-9 November 2016; pp. 53-55.

20. Martynov, V.V.; Nikulina, T.V.; Shokhin, I.V.; Terskov, E.N. Contributions to the fauna of invasive insects of Ciscaucasia. Field Biol. J. 2020, 2, 99-122. [CrossRef]

21. Balacenoiu, F.; Buzatu, A.; Dragos, T.O.; Alexandru, M.A.; Nețiu, C. Occurrence of invasive insects on woody plants in the main green areas from Bucharest city. Not. Bot. Horti Agrobot. Cluj-Napoca 2020, 48, 1649-1666. [CrossRef]

22. Martynov, V.V.; Nikulina, T.V.; Shokhin, I.V. Modern distribution of invasive dendrophilic insects in the Rostov region. Subtrop. Ornam. Hortic. 2017, 63, 175-182.

23. Hijmans, R.J.; Guarino, L.; Cruz, M.; Rojas, E. Computer tools for spatial analysis of plant genetic resources data: 1. DIVA-GIS. Plant. Gen. Res. Newsl. 2001, 127, 15-19.

24. Buga, S.V.; Zhorov, D.G.; Leshchinskaya, N.V.; Stekolshchikov, A.V. Aphids of the family Eriosomatidae (Insecta: Homoptera) in Belarus. Zoosyst. Ross. 2016, 25, 226-232. [CrossRef]

25. Siegert, N.W.; McCullough, D.G.; Liebhold, A.M.; Telewski, F.W. Dendrochronological reconstruction of the epicentre and early spread of emerald ash borer in North America. Divers. Distrib. 2014, 20, 847-858. [CrossRef]

26. EPPO Global Database. Available online: https://gd.eppo.int/taxon/PROCFX (accessed on 2 July 2021).

27. GBIF.org. GBIF Occurrence Download. Available online: https:/ /doi.org/10.15468/dl.5fetzgji (accessed on 6 July 2021).

28. European Alien Species Information Network. Available online: https:/ / easin.jrc.ec.europa.eu/spexplorer/search/searchpaged (accessed on 2 July 2021). 
29. Orlova-Bienkowskaja, M.J.; Drogvalenko, A.N.; Zabaluev, I.A.; Sazhnev, A.S.; Peregudova, E.Y.; Mazurov, S.G.; Komarov, E.V.; Struchaev, V.V.; Martynov, V.V.; Nikulina, T.V.; et al. Current range of Agrilus planipennis fairmaire, an alien pest of ash trees, in European Russia and Ukraine. Ann. For. Sci. 2020, 77, 1-14. [CrossRef]

30. Orlova-Bienkowskaja, M.J.; Bieńkowski, A.O. Modeling long-distance dispersal of emerald ash borer in European Russia and prognosis of spread of this pest to neighboring countries within next 5 years. Ecol. Evol. 2018, 8, 9295-9304. [CrossRef] [PubMed]

31. Orlova-Bienkowskaja, M.J. Ashes in Europe are in danger: The invasive range of Agrilus planipennis in European Russia is expanding. Biol. Invasions 2014, 16, 1345-1349. [CrossRef] 